\title{
統計的パターン認識に基づいたボールエンドミルによる切削面の外観検査*
}

\author{
岡本 謙 ${ }^{* 1}$, 森重 功一 ${ }^{* 2}$
}

\section{Quality Judgment of a Machined Surface with a Ball End Mill Based on Statistical Pattern Recognition}

\author{
Ken OKAMOTO*1 and Koichi MORISHIGE \\ ${ }^{* 1}$ Department of Mechanical Engineering and Intelligent Systems, The University of Electro-Communications \\ 1-5-1 Chofugaoka, Chofu, Tokyo 182-8585, Japan
}

This study is related to automation of polishing process by using an industrial robot. In polishing process, full automation of polishing operation has not been achieved due to the difficulty in visual inspection. Judgment of polishing sufficiency has been performed by skilled workers. In this study, the surface after milling process is the target for polishing. In the previous report, the generation of robot program for polishing operation based on CAD data was already proposed. Focusing on the periodicity of cutter mark patterns on milling surface, we proposed an automatic judgment of polished surface quality. This method is based on the image processing which uses Discrete Fourier Transformation. In order to capture images of the polished surface, a CCD camera was mounted on a 6-axis controlled robot hand. However, the image processing method proposed in previous report could not judge the curved cutter mark patterns because the periodicity of those patterns is not uniform. The objective of this report is the development of automatic judgment method for non-periodic cutter mark patterns. We developed a judgment method which uses statistical pattern recognition as a means to judge the existence of cutter marks. As a result, a system that allows the automatic polishing that includes the surface quality judgment is developed.

Key Words : Automation, Polishing, Milling Surface, Image Processing, Image Recognition, Industrial Robot

\section{1. 序論}

製造業の生産現場では, 単純な繰り返し作業や危険な作業から労働者を解放するため, 溶接や組立といった樣々 な工程で産業用ロボットが導入されてきた．しかしながら，研磨作業は熟練した技術と感覚が必要であり，自動化 が困難とされる .

先行研究 $^{(1)}$-(4)では, 3D-CAD データを用いたロボットプログラムの生成など, 産業用ロボットによる研磨作業 の自動化に取り組んできた . エンドミルによる切削面の研磨を対象として, 研磨・撮像・外観検査といった一連 のプロセスの自動化を目指している . 近年では, ロボットシステムにカメラを装着して , 製品を検査するシステ 厶の開発が盛んである ${ }^{(5)}$. 先行研究においても, ロボットハンドに CCD カメラを装着して加工面を撮像し，この 画像を処理して評価することで，外観検査の自動化を実現した．

本研究は, 研磨作業における外観検査工程の自動化を目的としている.先行研究における外観検査 ${ }^{(3),(4)}$ は, 切れ 刃による断続切削やピックフィードによるカッターマークの周期性に着目し, 離散フーリエ変換 (Discrete Fourier Transform, DFT) によって , パワスペクトラム画像 (Power Spectrum Picture, PSP) を比較・評価するものであった . 図 1(a) の走査線加工面に対して DFT を適用すると，図 1(b) に示す PSP が得られる . 走査線加工面の周期性が縞状 のスペクトラムとして現れており, 研磨良好面のPSP と比較することで研磨不良を判定した．しかしながら，工

* 原稿受付 2013 年 3 月 14 日

*1 学生員, 電気通信大学大学院 情報理工学研究科 知能機械工学専攻 ( ( 182-8585 東京都調布市調布ヶ丘 1-5-1)

*2 正員, 電気通信大学大学院 情報理工学研究科 知能機械工学専攻

E-mail:m-shige@mce.uec.ac.jp 
具経路が複杂倠に折れ曲がった図 1(c)のような加工面では, 図 1(d) のように周期性が多方向に分散し, 図 1(b)のよ うな縞状のスペクトラムが明確に現れないことから，研磨不良の判定が困難であった．

本研究では, 周期性のないカッターマークにも対応できる外観検査を確立するために, 統計的パターン認識を利 用した検査手法について検討した . 既知のカッターマーク画像群から特徵量を求め, 研磨面の撮像画像とのマッチ ングを行うことで, カッターマークの有無を直接的に判定する . 検査工程の自動化に関する研究は多く ${ }^{(6)}$ - (8) , 実 用事例も多いが，統計的パターン認識を利用してカッターマークを直接的に判定した事例はない .

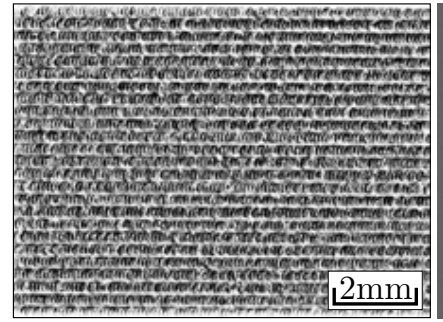

(a) By scan milling

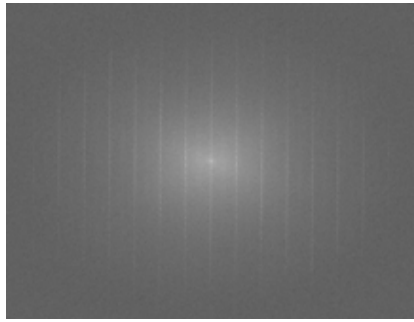

(b) Power Spectrum Picture of (a) $(1,620 \times 1,250 \mathrm{px})$

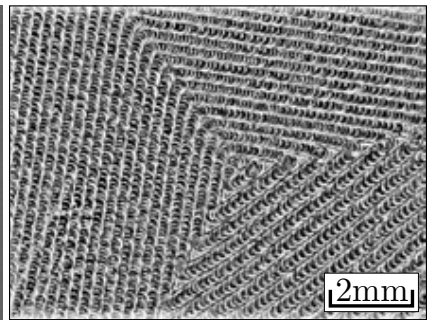

(c) By bended milling path

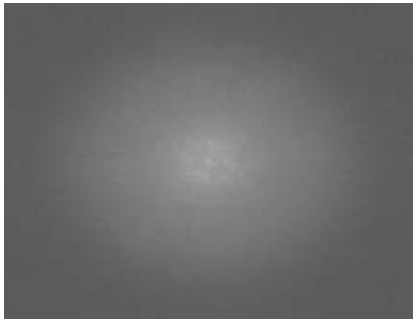

(d) Power Spectrum Picture of (c) $(1,620 \times 1,250 \mathrm{px})$

Fig. 1 Captured images of milling surfaces and results of DFT (Power Spectrum Picture, PSP)

\section{2. システムの構成と研磨プログラムの流れ}

システムの構成を図 2 に示す. 開発した CAMソフトウェアによって生成されたロボットプログラムを, RS-232C 通信でロボットコントローラへ転送する . 使用したロボットは, 6 軸多関節形産業用ロボットファナック社製 S-700 である.グラインダと CCD カメラを交互に付け替えて，研磨および撮像を行う．表 1 に，使用した画像機器の仕 樣を示す．研磨工程は，以下の処理を繰り返す：(1)研磨を行う.(2)工具をカメラに付け替える . (3) 研磨面を撮像 し，画像処理により良否判定を行う．(4) 研磨面が良好であれば研磨を終了する．不良であればカメラを研磨工具 に付け替える．

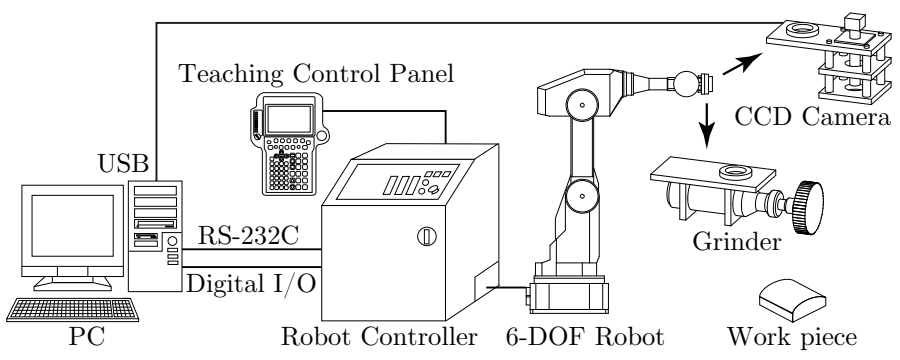

Table 1 Specifications of capturing system

\begin{tabular}{l|c} 
Camera & Lumenera Lw23M \\
Resolution & $1,616[\mathrm{px}] \times 1,216[\mathrm{px}]$ \\
Sensor type & $\mathrm{CCD}$
\end{tabular}

Lens

Edmund Optics VZM 450i

Imaging area

$9.3[\mathrm{~mm}] \times 6.8[\mathrm{~mm}]$

Fig. 2 Polishing system configuration

3. 統計的パターン認識によるカッターマークの判定

\section{$3 \cdot 1$ 統計的パターン認識を用いた外観検査}

統計的パターン認識の手法として , Rainer Lienhart ら ${ }^{(9)}$ にっって改良された Viola-Jones の手法 ${ }^{(10)}$ を利用した . こ れは，既知の学習画像群の特徵量を，機械学習によって分類する手法である.

まず，学習画像群として既知の画像を大量に入力する . 学習画像群は, カッターマーク画像 (Positive samples) と, カッターマークに無関係な画像 (Negative samples) の2 通りを用意する.与えられた学習画像群を, ピクセル のデータ列から, より機械学習に適した特徵量データに変換し, 弚の傾向を機械学習によって学習する.

次に, 得られた学習結果データを用いて未知画像を評価する. 学習結果データと未知画像の特徵量データを比 較することで, 未知の画像中にカッターマークが含まれるか否かを判定する . 


\section{$3 \cdot 2$ Haar-like 特徵量}

\section{3·2·1 Haar-like 特徵の種類}

特徵量として , 矩形特徵 (Rectangle features) の一種である Haar-like 特徵 (Haar-like features) を用いた . Haar-like 特徵は，画像の中の特定領域の輝度值を手がかりとして，光の画像が目的の才ブジェクトであるか否かを識別す る.一つの Haar-like 特徵は, 隣接する $n$ 個の小矩形から構成される . 画像が与えられると，各小矩形領域ごとに 平均輝度值が計算され, 弚れらの各領域間での差が, 予め学習しておいたしきい值を超えるか否かによって, 識 別結果が得られる.

一つの Haar-like 特徵は, 小矩形領域の数・並び方・座標・大きさという4つのパラメタを持つ.これらのパラ メタにより, Haar-like 特徵は無数の組み合わせを持つ．また，各矩形領域が 45 度傾いた，斜めの特徵量 (Tilted Haar-like features) も存在する.

Haar-like 特徵の種類が多ければ，炎の中に優秀な Haar-like 特徵が含まれる可能性が高くなるが，機械学習にお ける計算量は増加する．光のため，小矩形の数および並び方を，画像のエッジ部に強く反応するエッジ特徵 (図 3(a))，線特徵 (図 3(b))，および中点特徵 (図 3(c)) のパターンに限定している . この条件の下では, 20×20ピクセ ルの画像がカッターマークパターンであるかどうかを識別する Haar-like 特徵を学習するとき, Haar-like 特徵の組 み合わせは約 13 万通りとなる .

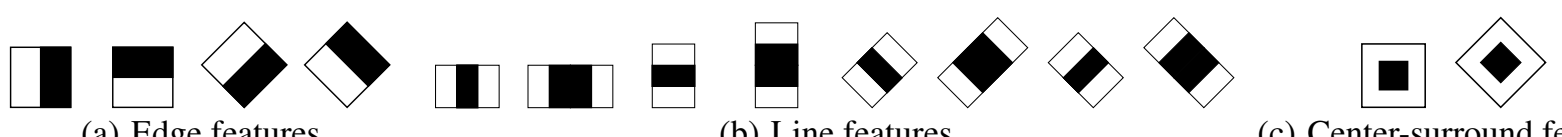

(a) Edge features

(b) Line features

(c) Center-surround features

Fig. 3 Rectangle areas of Haar-like features (black and white areas have negative and positive weights respectively)

無数に存在する Haar-like 特徵の中には, カッターマークの識別に適したものもあれば , 弚うでないものもある . カッターマークの識別に適した Haar-like 特徵として，図４のように一刀分の刀跡にまたがった矩形領域があげら れる .この Haar-like 特徵は, カッターマーク以外の画像においては, 高い特徵量を出力するとは限らない . この ような統計的な性質の差は，統計的パターン認識の手法によって機械学習することで分類できる .

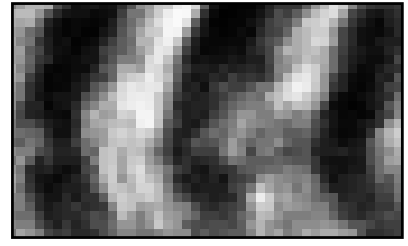

(a) Cutter mark image

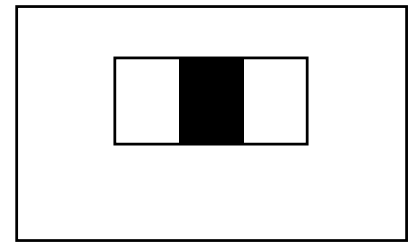

(b) Haar-like feature

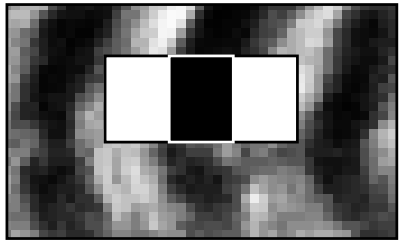

(c) Applying feature

Fig. 4 Application example of Haar-like feature

\subsection{2 オブジェクト 分類問題の定式化}

Haar-like 特徵によるオブジェクト分類問題を定式化する .まず，「ある一般の画像 $F$ 内の領域 $q$ に存在する部分 画像 $I_{q}$ がカッターマークであるか否かを分類する」という問題を設定する (図 5) . ある Haar-like 特徵 $r$ の $k$ 個 目 $(k=1 \cdots, n)$ の小矩形が占める領域を $s_{k}$ とおくと，領域 $s_{k}$ の部分画像は $I_{s_{k}}=\left\{\operatorname{image}(x, y) \mid(x, y) \in s_{k}\right\}$ と 定義される. 各小矩形 $s_{k}$ には黑色・白色を示すラベル $c_{k} \in\{-1,1\}$ が割り振られる.このとき，領域 $s_{k}$ の平均 輝度值は，以下の式 (1) で与えられる．

$$
m\left(I_{s_{k}}\right)=\frac{1}{A_{s_{k}}} \sum_{x \in s_{k}} \sum_{y \in s_{k}} \operatorname{image}(x, y)
$$

ここで, $A_{s_{k}}$ は $s_{k}$ の面積を示す.いま，一つの Haar-like 特徵を $r=\left\{s_{k}, c_{k}\right\}_{k=1}^{n}$ と表すと，入力画像 $I_{q}$ に対する $r$ の特徵量 $f$ は, 次の式 (2) で定義される .

$$
f\left(r, I_{q}\right)=\sum_{k=1}^{n} c_{k} m\left(I_{s_{k}}\right)
$$


すなわち, 特徵量 $f$ は, 白色小矩形領域の平均輝度値と黑色小矩形領域の平均輝度値の差である.この特徵量 $f$ による分類関数として，以下のしきい值関数 $h$ を用いる .

$$
h\left(r, I_{q}\right)= \begin{cases}1 & \text { if } p f\left(r, I_{q}\right)>p \theta \\ 0 & \text { otherwise }\end{cases}
$$

ここで, $p \in\{-1,1\}$ および $\theta \in \mathbb{R}$ は，機械学習によって固定される值である .すなわち，各小矩形の輝度值の差 $f$ が一定值 $\theta$ より大きい $(p=1$ のとき) あるいは小さい $(p=-1$ のとき)ならば， 入力画像はカッターマークであ ると判断される.

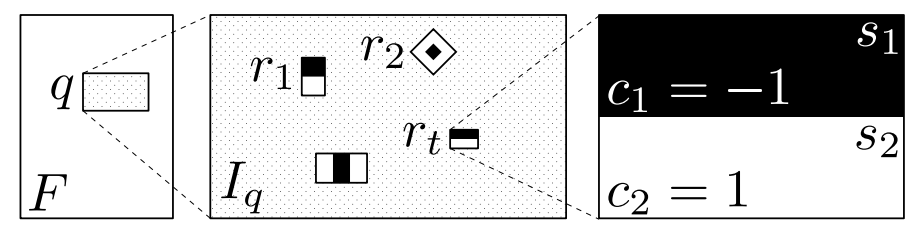

Fig. 5 Pattern recognition diagram using Haar-like features

\section{$3 \cdot 3$ AdaBoost による機械学習}

AdaBoost ${ }^{(11)}$ は, 精度が低い分類器を複数組み合わせることで, 高精度の分類器を構築する機械学習のアルゴリ ズム $\left(\right.$ ブースティング ${ }^{(12)}$ ) である. 基礎となる精度が低い分類器は弱分類器 (Weak classifier) と呼ばれ，ここで は一つの Haar-like 特徵が一つの弱分類器となる. 弱分類器を組み合わせて作られる最終的な分類器を, 強分類器 (Strong classifier) と呼ぶ . 強分類器は, 各弱分類器の「重み付き多数決」の形として出力される (図 6) .

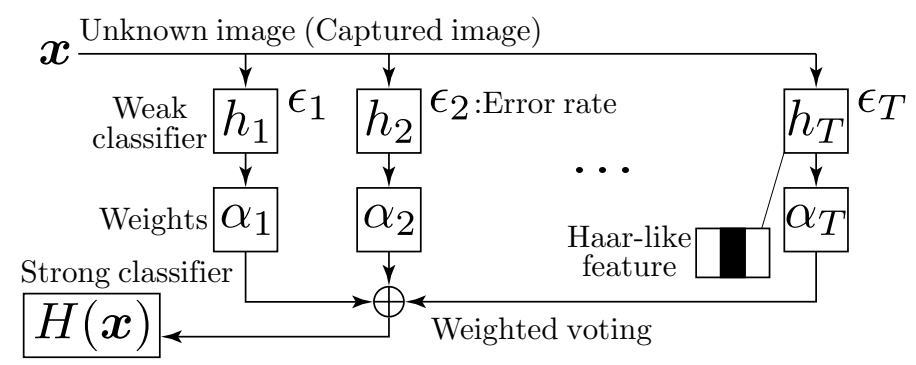

Fig. 6 Fundamental idea of AdaBoost algorithm

AdaBoost では, 入力された既知の学習画像群を用いて学習を行い，弚の学習結果を踏まえて逐次重みの調整を 繰り返す (図 7) . 以下にAdaBoost の学習アルゴリズムを示す.

1) 学習画像群 $\left\{\boldsymbol{x}_{i}, y_{i}\right\}_{i=1}^{n}$ を与える (図 7(1) . ここで, $\boldsymbol{x}_{i}$ は既知画像， $y_{i} \in\{0,1\}$ は教師信号を示す . $y_{i}=1$ の とき, $\boldsymbol{x}_{i}$ はカッターマーク画像である .

2) 学習画像の重みの初期値 $w_{t, i}$ を生成する (図 7(2) ） ここで $m$ と $l$ は, 非カッターマーク画像とカッターマー クの画像の数である .

$$
w_{t, i}= \begin{cases}\frac{1}{2 m} & \text { if } y_{i}=0 \\ \frac{1}{2 l} & \text { otherwise }\end{cases}
$$

3) 以下の処理を繰り返す $t=1, \cdots, T$.

- 画像の重み $w_{t, i}$ を正規化する (図 73) .

$$
w_{t, i} \leftarrow \frac{w_{t, i}}{\sum_{j=1}^{n} w_{t, j}}
$$

- Haar-like 特徵 $r_{j}$ のパラメタ $p_{j}, \theta_{j}$ を最適化し，重み付き誤り率 $\epsilon_{j}=\sum_{i} w_{t, i}\left|h_{j}\left(\boldsymbol{x}_{i}\right)-y_{i}\right|$ を最小にす る (図 74) . 
- 全ての Haar-like 特徵の中で重み付き誤差 $\epsilon_{j}$ が最小のものを $t$ 番目の弱分類器 $h_{t}$ に採択する (図 7(5) .

・結果の信頼度 $\beta_{t}$ を求める.

$\beta_{t}=\frac{\epsilon_{t}}{1-\epsilon_{t}}$

・学習画像の重みを更新する (図 76) .

$w_{t+1, i}= \begin{cases}\beta_{t} w_{t, i} & \text { if } h_{t}\left(\boldsymbol{x}_{i}\right)=y_{i} \\ w_{t, i} & \text { otherwise }\end{cases}$

4) 最終的な強分類器を構築する (図 77) .

$$
\begin{aligned}
& H(\boldsymbol{x})= \begin{cases}1 & \text { if } \sum_{t=1}^{T} \alpha_{t} h_{t}(\boldsymbol{x}) \geq \frac{1}{2} \sum_{t=1}^{T} \alpha_{t} \\
0 & \text { otherwise }\end{cases} \\
& \alpha_{t}=-\log \left(\beta_{t}\right)
\end{aligned}
$$

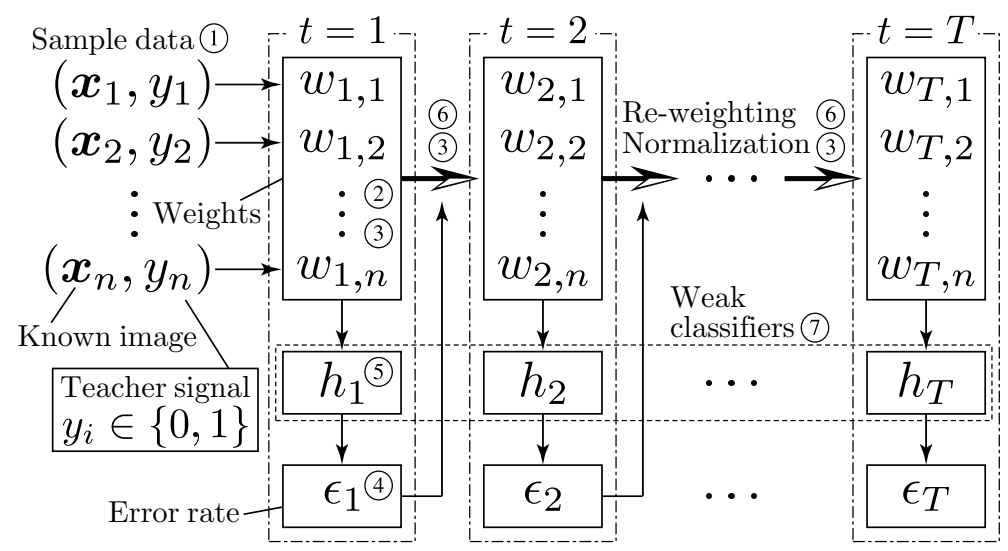

Fig. 7 Basic flow of selecting weak classifiers in AdaBoost algorithm

個々の学習画像の重み $w_{t, i}$ は, 初期状態ではカッターマーク画像および非カッターマーク画像に対して, 弚れ 光れ均等に設定される．学習画像の重み $w_{t, i}$ は, 弱分類器が一つ選ばれる度に更新される . 具体的には, 式 (7)に 従って $h_{t}$ か誤って分類した画像の重みを相対的に大きくする . 光のため, 次の反復では , これまでの反復におい て分類が困難であった画像をより高精度に分類できる Haar-like 特徵が採択されやすくなる．

$\alpha_{t}$ は，採択された Haar-like 特徵に与えられる重みである. $\epsilon_{t} \rightarrow 0$ ならば $\beta_{t} \rightarrow 0, \epsilon_{t} \rightarrow \frac{1}{2}$ ならば $\beta_{t} \rightarrow 1$ であ る.これにより, 精度の高い弱分類器ほど, 重み $\alpha_{t}$ が大きくなる.最終的な強分類器 $H(\boldsymbol{x})$ は, 採用された各弱 分類器 $h_{t}(\boldsymbol{x})$ の重み付き線形和の形で構築される.

3.4 カッターマーク検出の前処理

Haar-like 特徵量は図形の明るさの差で与えられ，撮像時の照明の偏りが判定結果に影響を及ぼすことが考えら れるため，全体的に均一な明るさになるように補正する．画像の明るさに対応する成分は，画像の長周期成分で ある．したがって，撮像画像にハイパスフィルタを適用することで明るさの成分は除去され，照明の偏りを補正 することができる．八イパスフィルタとして，式(10)で定義した指数関数を用いている .

$$
\operatorname{HPF}(u, v)=1-\exp \left(-\frac{u^{2}+v^{2}}{V}\right)
$$

これは, 周波数の原点付近 $(u, v \approx 0)$ の低周波数成分を滑らかに遮断する形状であり， $V$ の值で遮断周波数を制御 している . 図 8(a)の入力画像のパワスペクトラム (図 8(b)) に対して $\operatorname{HPF}(u, v)$ を重ねあわせると，図 8(c) のパワ スペクトラムが得られる .これを逆フーリエ変換することで, 図 8(d) のような明るさが均一に補正された画像が 得られる。 


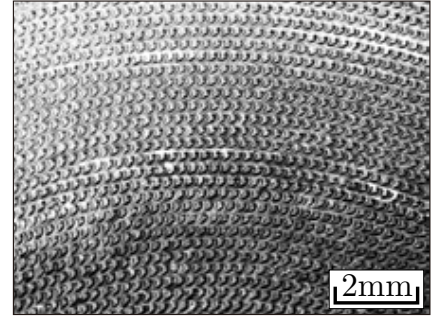

(a) Source image

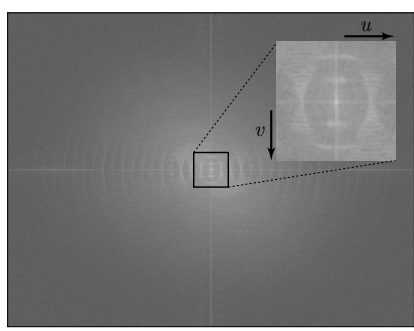

(b) PSP of (a)

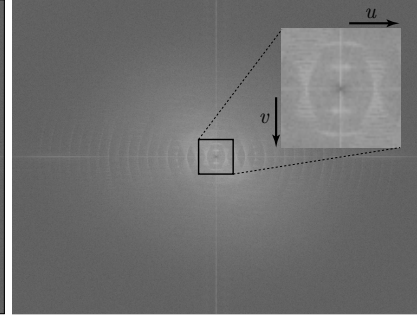

(c) Applying HPF

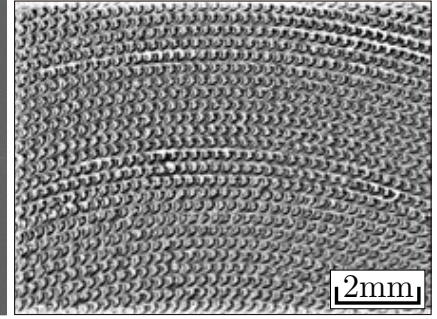

(d) IDFT results of (c)

Fig. 8 Effect of removing luminance bias

3.5 カッターマークの探索

矩形領域で表現される探索空 (Sub-window) を, 図 9(a)のように画像中で走査させ , 弚の個々の部分領域を分類 器を用いて判別し , カッターマークを探索する. 学習画像群とは異なる解像度のカッターマークも検出できるよ うに探索空に拡大倍率 (Scale factor) を乗算し，スケールを徐々に大きくしながら複数回の走査を行う．

樣々なスケールの探索密で複数回の探索を実行するため, カッターマークらしきオブジェクトの周囲では, 図 9(b) のように複数のスケールでカッターマークの候補矩形が検出される .ここでは, 全ての候補矩形群を素集合 データ構造 (Disjoint-set data structure) と呼ばれるデータ構造に格納し, 類似性の高い候補矩形群から一つの矩形 (図 9(c)) を求める.素集合データ構造とは, 互いにオーバーラップしない集合に分割して保持するデータ構造で ある

矩形領域の類似性として，顔認識などの処理では矩形端点の相対的差異が使われることが一般的であるが，本 研究では矩形の重心位置を類似性の尺度とした .これは樣々な角度て矩形領域を検出するためであり，重心位置が 近い矩形領域は一つのカッターマークを示す矩形群であるとみなしてグループ化した .

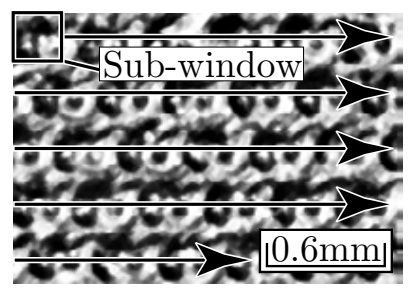

(a) Scanning search

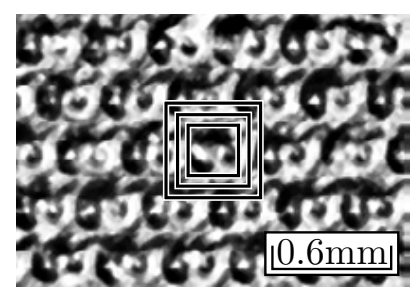

(b) Detected sub-windows

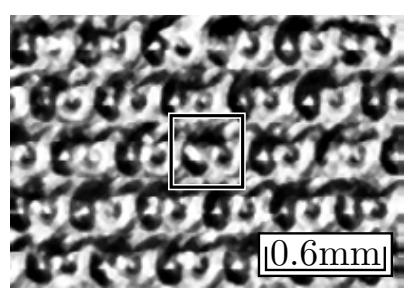

(c) Grouped rectangle

Fig. 9 Detection and grouping of sub-windows

\section{4. 学習画像群収集の高能率化}

統計的パターン認識では大量の学習サンプル画像を必要とし，弚の収集における作業量の膨大さが，画像認識 実現の阻害要因の1つとなっている . 文字認識の分野では, 原画像の変形モデルを用いて学習画像を自動生成す る生成型学習法 ${ }^{(13)}$ が提案されており, 実用化が進んでいる. 本研究では, 切削面の撮像画像を用いて, 大量の学 習サンプル画像を効率的に収集する手法を提案する .

\section{$4 \cdot 1$ 学習画像を得るための加工経路}

Viola-Jones の手法では，学習サンプルとして大量の既知画像を必要とする.多樣な加工条件で切削されたカッ ターマークパターンを得るために, 図 10(a)のような切削経路を用いた .この経路は, 複数のセル領域て構成され る .1 つのセル内は, 加工条件一定の走査線加工が行われる . 図 10(a)が示すように, 送り速度およびピックフィー ド量を等比級数的に各セルごとに 1.1 倍することで, 各セルを異なる加工条件で切削する . 図 10(b) は加工された 試験片であり，全体で 100 通りの加工条件に対応している .

\section{$4 \cdot 2$ 大量の学習画像を一度に得るトリミング処理}

図 11 は，回転数 5,000[rpm] における，送り速度 605[mm/min] および 666[mm/min] の加工面の撮像画像である. カッターマークパターンは, 主軸回転数と送り速度の比によって, 図 11(a), (b) のように, 異なるパターンが千鳥 状に現れる .このような画像から，効率的に 1 刃分のカッターマーク画像をトリミングする方法を開発した . 


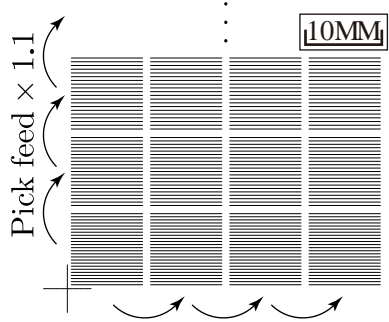

Feed rate $\times 1.1$

(a) Tool path of test piece

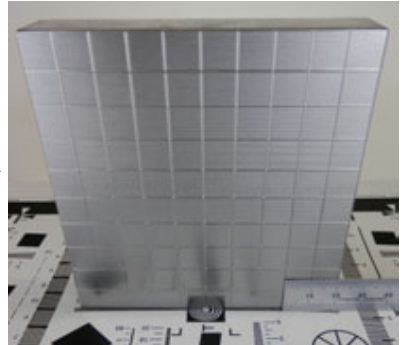

(b) Machined surface

Fig. 10 Test piece machined by various machining conditions used for machine learning sample

トリミング処理は，図 12 の (a) から (f) の順に行われる .

(a) 工具送り方向が水平となるように画像を回転した後, 矩形領域を指定する . この矩形は, 幅が 1 刃あたり送 り量の整数倍，高さがピックフィード量の整数倍となるよう，図 12(a)のように指定する .

(b) 作業者がピックフィードの列数を入力することで, ピックフィード量の間隔で画像を分割する .

(c) 分割した各ピックフィード列を, 図 12(c)のようにオフセットする . 1 刃あたりのカッターマークが鉛直方向 に規則正しく整列するようなオフセット量を作業者が目視で探す．

(d) (c) において , オフセットによって押し出されたカッターマークパターンは , 図 12(d)の矢印のように移動し， 光れ光れ列の反対側に接合される。

(e) 水平方向のカッターマークの数を入力する .このカッターマークの数に従って , 図 12(e) の縦線のように画像 を分割することで，1 刃分のカッターマークが得られる .

(f) (d) においてカッターマークを移動させた際 , 図 12(f) の矩形で示したカッターマークは不連続となるため, 破 棄される.

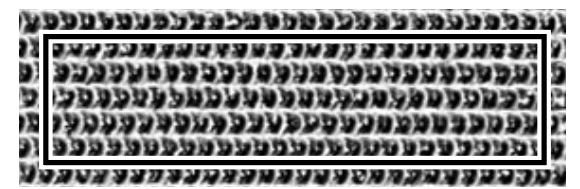

(a) Setting of trimming area

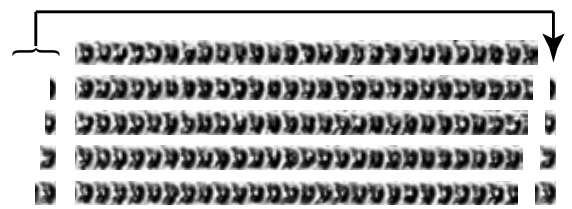

(d) Relocating

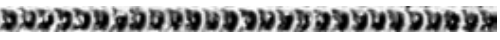

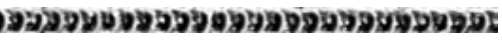

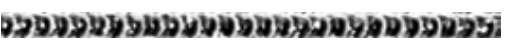

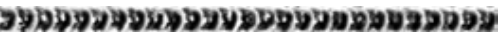

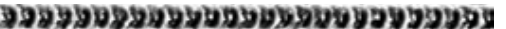

(b) Dividing horizontally

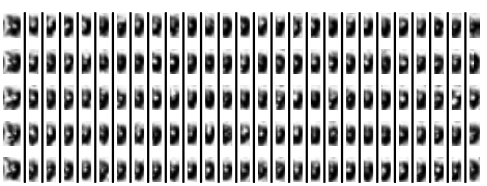

(e) Dividing vertically

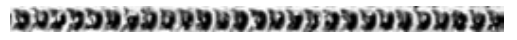

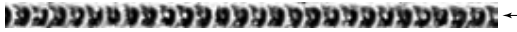

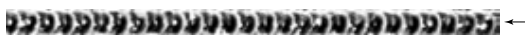

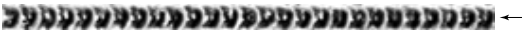

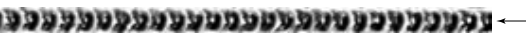

(c) Offsetting

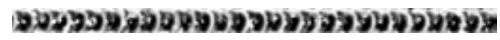

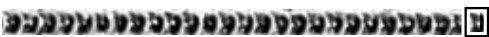

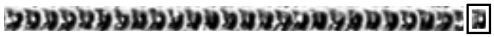

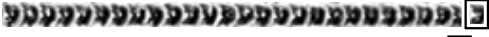

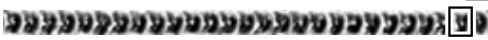

(f) Rejecting non-contiguous

Fig. 12 Trimming processes of cutter marks image

図 13(a) は，トリミング処理プログラムで得られた 1 刀分のカッターマーク画像 (Positive samples) である . 比較 のための非カッターマーク画像 (Negative sample) を図 13(b) に示す . これらは, 研磨後の撮像画像 (良品画像, ス クラッチパターン) から無作為に抽出した .

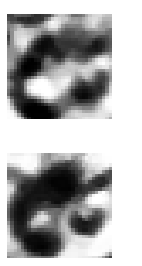

(a) Positive samples (cutter mark pattern)
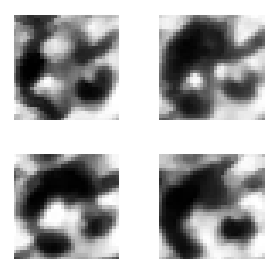
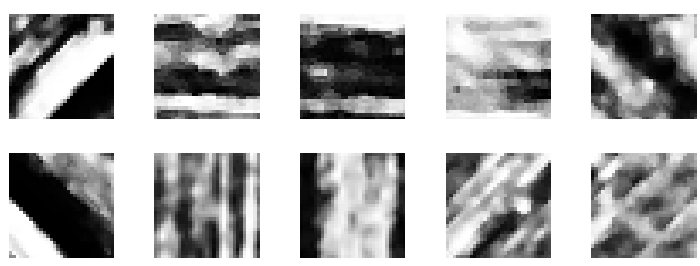

(b) Negative samples (scratch pattern)

Fig. 13 Examples of positive and negative samples $(20 \mathrm{px} \times 20 \mathrm{px})$ 
以上の手順で収集したカッターマーク画像は，図 13(a)のように，すべてが鉛直方向に整列している．このよう な画像を機械学習した分類器では, 鉛直方向のカッターマーク画像のみが検出されやすい.しかし, 評価対象の撮 像画像では工具送り方向は未知であり，樣々な方向をとり得る．乥こで，探索対象の撮像画像を回転させながら， 各回転画像に対して探索を行った。

\section{5. 基礎実験によるカッターマーク分類器の構築}

多樣な加工条件で得られた学習画像群を用いて , 分類器を構築する . 学習画像となるサンプルの加工条件は， ピックフィード量が $0.2[\mathrm{~mm}]$ から $0.471[\mathrm{~mm}]$ の範囲内で 20 通り，送り速度が $500[\mathrm{~mm} / \mathrm{min}]$ から 1,178 [mm/min] の範囲内で 10 通りの条件を組み合わせ , 200 通りを用意した . ポジティブサンプル数は 11,943 , ネガティブサン プル数は 5,000 である .

図 14 は，機械学習の過程で選択された Haar-like 特徵である . 図 13(a)のようなカッターマークの図形を検出す ることに適した矩形群が, 逐次採択される過程か現れている.

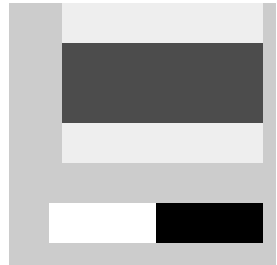

(a) $t=2$

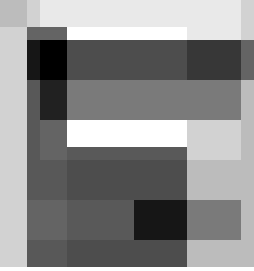

(b) $t=5$

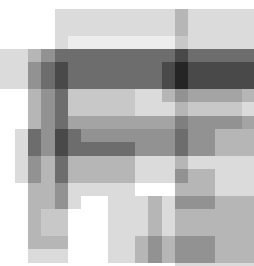

(c) $t=25$

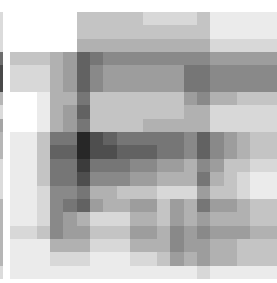

(d) $t=50$

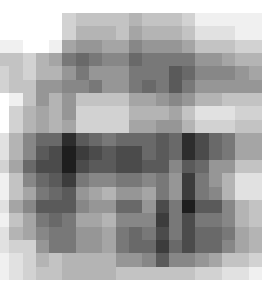

(e) $t=100$

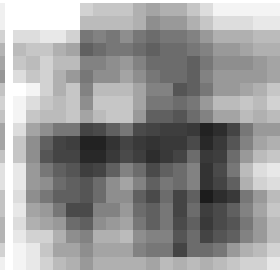

(f) $t=200$

Fig. 14 Selected Haar-like features

図 15 は，構筑した分類器を用いてカッターマークを検出した結果である . 図 15(a) の撮像画像を 20[deg] きざみ で $0[\mathrm{deg}]$ から $340[\mathrm{deg}]$ まで反時計回りに回転させ , カッターマークを探索した . このときの，回転の中心は，撮 像画像の中心である . 図 15(b) において , 彩度 (Saturation) の高い楕円形は, クラスタリング処理によって得られ た類似度が高い検出矩形群の代表矩形の位置を示し，1,559 個のカッターマークが検出された .これらの楕円形の 短軸および長軸は, 検出矩形の短辺および長辺に乥れ光れ対応している. カッターマークは, 撮像画像の切削経 路に沿うように断続的に検出された .

また, 彩度の低い楕円形は, 全ての検出矩形の位置を示している .これらの楕円形の色相 (Hue) は検出された回 転角度を示し，180 度周期で同じ色相となるように，図 15(b) に示す通りに定めた . 工具送り方向が同一の場所で は, 同じ傾向の色相を確認することができ, 同一の回転角度でカッターマークが検出されていることがわかる .

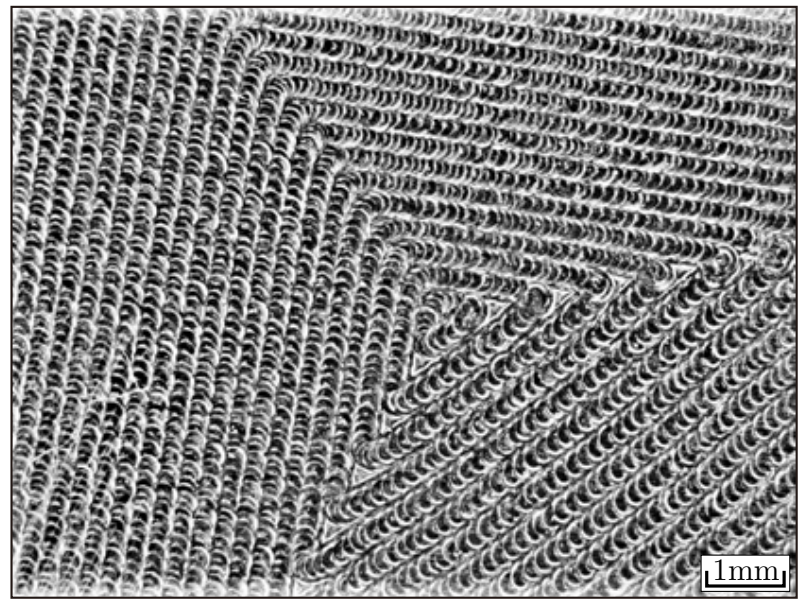

(a) Source image

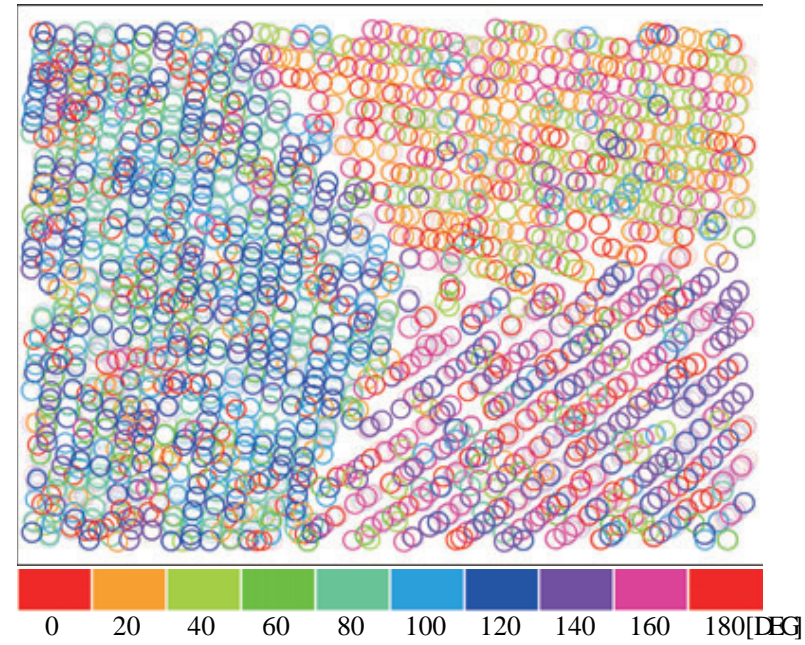

(b) Detected cutter marks and colors corresponding to detected angle, No. of detected: 1,559

Fig. 15 Result of cutter mark detection 


\section{6. 画像処理と分類器のパラメタ設定}

\section{$6 \cdot 1$ 照明条件の偏りの補正}

図 8(a) は, 得られた撮像画像の中で，照明条件の偏りか湿著に現れているものである . 式 (10)の $V$ は遮断周波 数を制御する変数であり，照明の偏りの成分を設定する .ここでは，周波数 $u$ および $v$ の值を -0.5 から 0.5 範 囲で正規化し， $V$ を $0<V \leq 1$ の範囲で変化させて，最適値を求めた .

図 16 に，各 $V$ を用いてハイパスフィルタを撮像画像に作用させた結果を示す．図 17 に, 各 $V$ 毎のカッター マーク検出数を示す.ここで $V=0$ は, 補正を適用していない画像を意味する. カッターマークは $V=0$ から $V=10^{-3}$ の範囲内で検出され, $V=10^{-2}$ 以上では, カッターマークは全く検出されなかった .

一方， $V<10^{-4}$ の範囲では， $V$ 值の増加に応じて検出数が増加している.この条件では照明条件の偏りが適切 に補正され, カッターマーク検出の精度が向上した $V=10^{-2}$ を超えると，図 $16(\mathrm{f}),(\mathrm{g}),(\mathrm{h})$ のように必要な周波 数領域も遮断されて画像か破綻したため, カッターマークの検出が不可能であった．以上の結果より，検出数が最 も多い $V=10^{-4}$ が最適であると結論づけ，実験ではこの值を用いた .

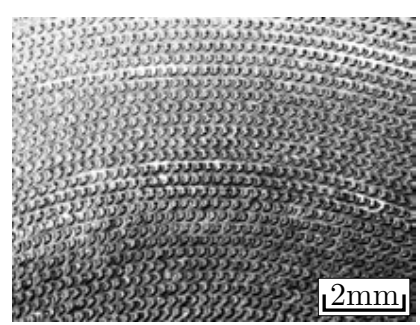

(a) $V=0$ (No processing)

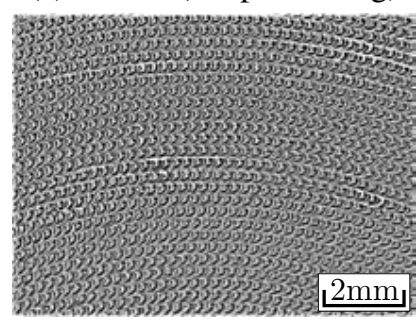

(e) $V=10^{-3}$

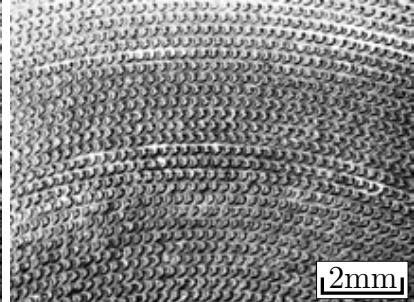

(b) $V=10^{-6}$

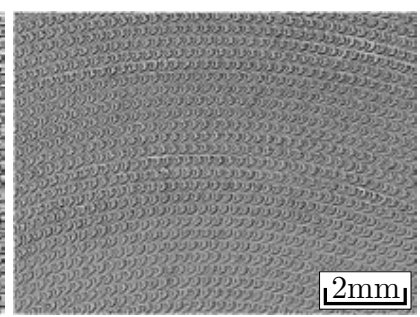

(f) $V=10^{-2}$

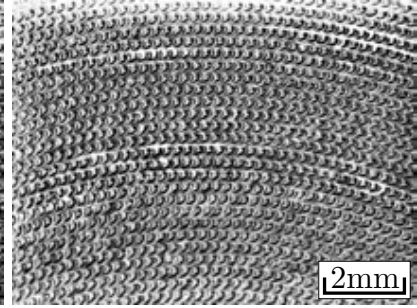

(c) $V=10^{-5}$

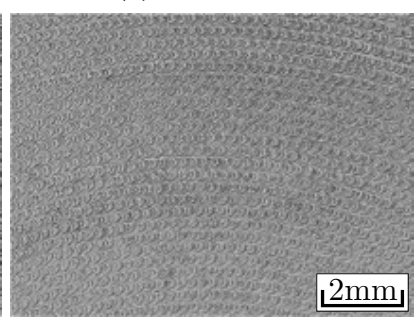

(g) $V=10^{-1}$

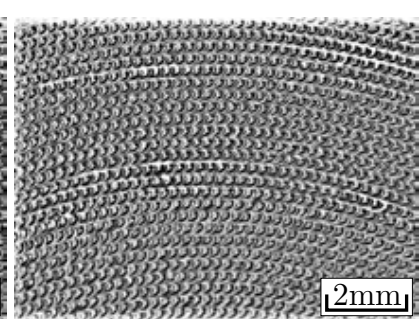

(d) $V=10^{-4}$

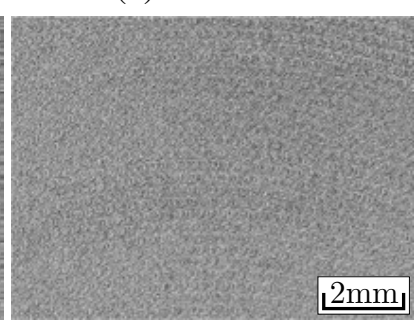

(h) $V=1$

Fig. 16 Effects of luminance bias correction associated with cutoff frequency $V$

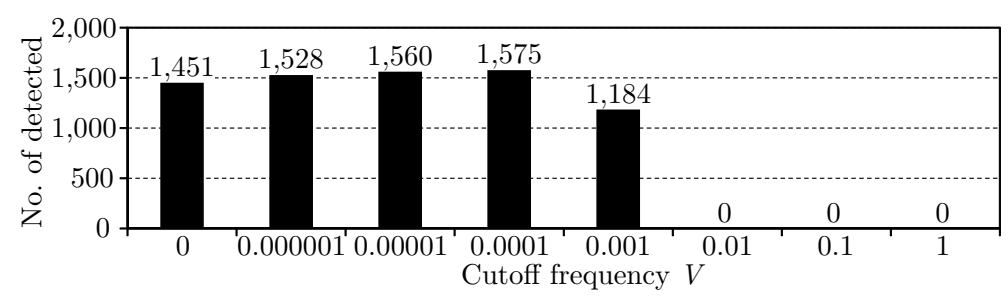

Fig. 17 Number of detected cutter marks associated with cutoff frequency $V$

\section{$6 \cdot 2$ カッターマーク検出のパラメタ設定}

探索空の拡大倍率 (Scale factor) が , カッターマーク検出の精度と計算時間に大きな影響を与える . 拡大倍率を 低く設定すれば, 探索莣のスケールの分解能が高くなるため, 検出の精度が向上するが, 計算時間は増加する .

図 18 は, 検索空の拡大率を 1.1 から 1.5 の範囲で変化させたときの処理時間およびカッターマーク検出数の平 均値を比較したものである. 平均值の算出には，40 サンプルの撮像画像を使用した .

処理時間は, (I) 照明条件の偏りの補正等の画像処理, (II) カッターマーク検出処理, (III) クラスタリング処理の 3 段階に分けて評価した .

評価の結果として , カッターマークの検出処理が処理時間の大半を占めることを確認した . 拡大倍率 1.5 倍の場 合では, 1.1 倍の場合の 2 倍を超える処理時間であった . クラスタリング処理は, カッターマークの検出数に応じ て計算量が増加する処理であり, 拡大倍率によって変化する .また，画像処理の時間は，入力画像の解像度に依存 
し，拡大倍率によらずほぼ一定である。

一方, 拡大倍率を高く設定することで, 検出の精度は明らかに悪化する (図 18(b)) . 本研究では, 試行した範囲 で最も検出精度の高い，拡大倍率 1.1 倍の場合の処理時間（約 12 秒）を許容し，これを実験で用いることにした． Sharma らの報告 ${ }^{(14)}$ によると, GPU 演算による Viola-Jones の手法の並列化によって, 毎秒 150 フレームの処理速 度が実現されている．GPU の利用によって，カッターマークの検出速度は，著しい高速化か望める．

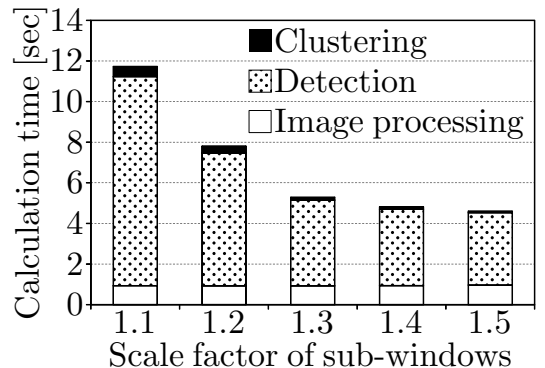

(a) Comparison of calculation time

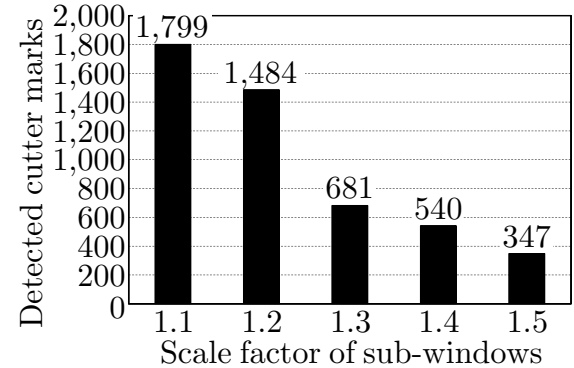

(b) Comparison of detected cutter marks

Fig. 18 Effects of scale factor (average of 40 samples)

\section{7. 研 磨 実 験}

\section{$7 \cdot 1$ 実験の条件}

研磨の対象として , 図 19 の曲面形状を採択した .これは式(11)で示され，曲率が連続的に変化する凹凸面である． スパイラル切削経路により，HPM1 プリハードン鋼をこの曲面形状に加工した . 加工条件は, 回転数 6,000[rpm] , 送り速度 $700[\mathrm{~mm} / \mathrm{min}]$, ピックフィード $0.3[\mathrm{~mm}]$, ボールエンドミル R5 である .

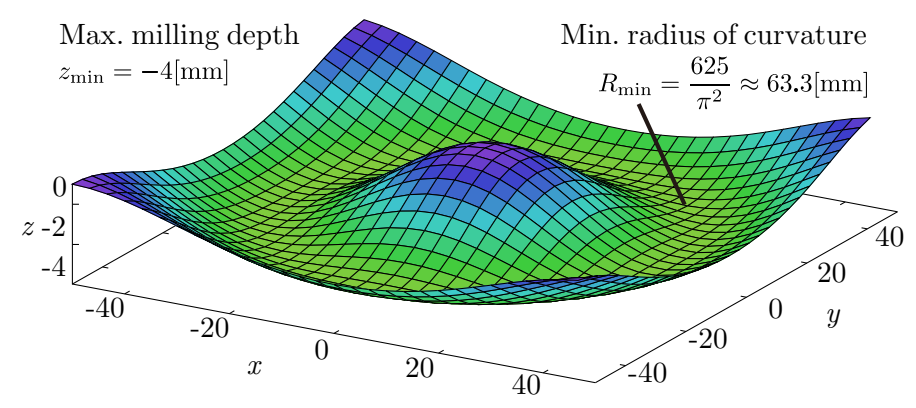

Fig. 19 Polishing target shape

$$
z=2 \cos \left(\frac{\sqrt{x^{2}+y^{2}}}{25 \sqrt{2}} \pi\right), \quad 0 \leq x \leq 50, \quad 0 \leq y \leq 50
$$

製作した研磨対象の表面粗さは，最小で $0.25[\mu \mathrm{mRa}]$ ，最大で $10.72[\mu \mathrm{mRa}]$ と，大きな差か計測された .これは， 曲面に対する 3 軸加工おいて , ボールエンドミルが加工面と接触する位置の違いに起因する . 表面粗さの最大值 は , ボールエンドミルの底面て切削された箇所で測定された .

研磨経路として，研磨能率の高いトロコイド曲線を用いた $x$ 方向へ研磨工具を送る「Type 1$\lrcorner$ の経路と, $y$ 方 向へ送る「Type 2」の 2 通りの経路を生成した .これら 2 通りの研磨経路を, 各研磨工程で交互に実行した . 各研 磨工程毎に，加工面に対して撮像を行った . 撮像点は $10[\mathrm{~mm}]$ 間隔で, 格子状に 64 点を設けた 。

\section{$7 \cdot 2$ 実験の結果と考察}

図 20 は, 研磨前後の試験片を比較したものである . 図 20(c)のように, 光沢面が得られるまで研磨を行った . 研 磨は, Type 1 の経路を 4 工程, Type 2 の経路を 3 工程の, 合計 7 工程を実行した . 図 20(b), (d) は, 測定した粗さ 曲線である . 測定点は, 最大の表面粗さが測定された場所であり，図 20(a), (c) に図示した箇所である . 研磨後の

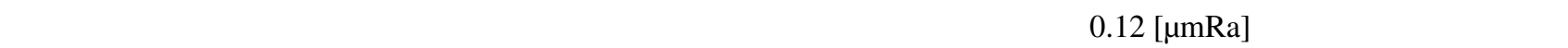
磨面であるといえる． 


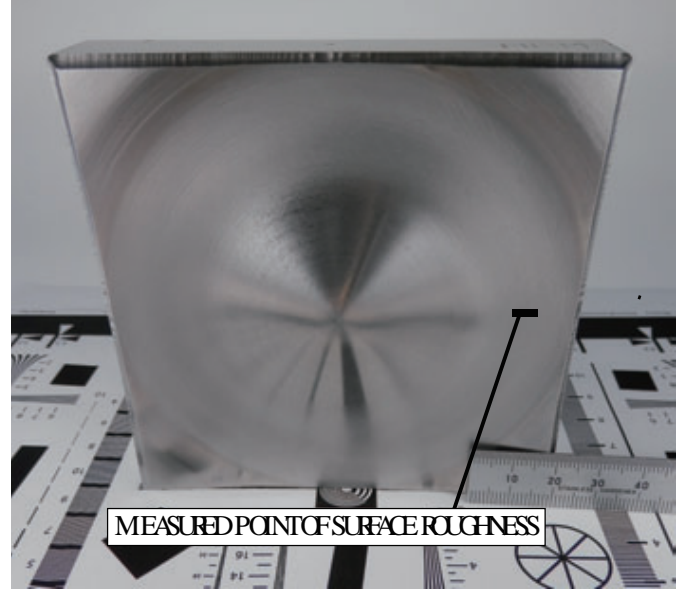

(a) Machined surface

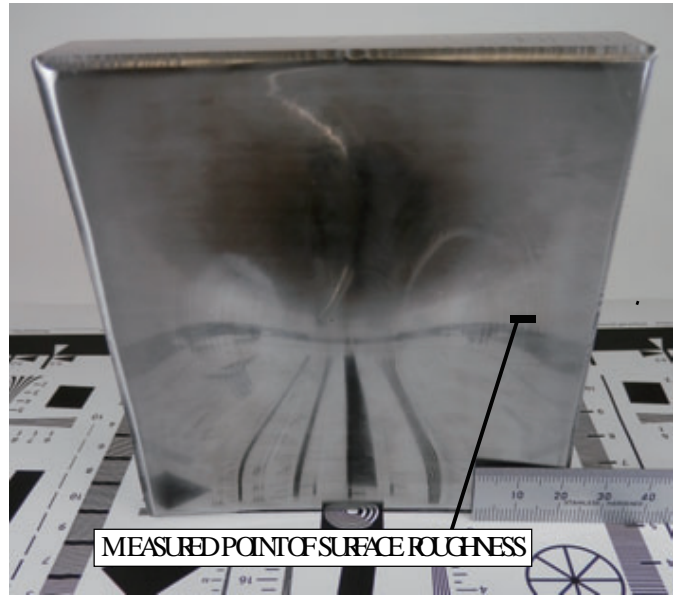

(c) After polishing

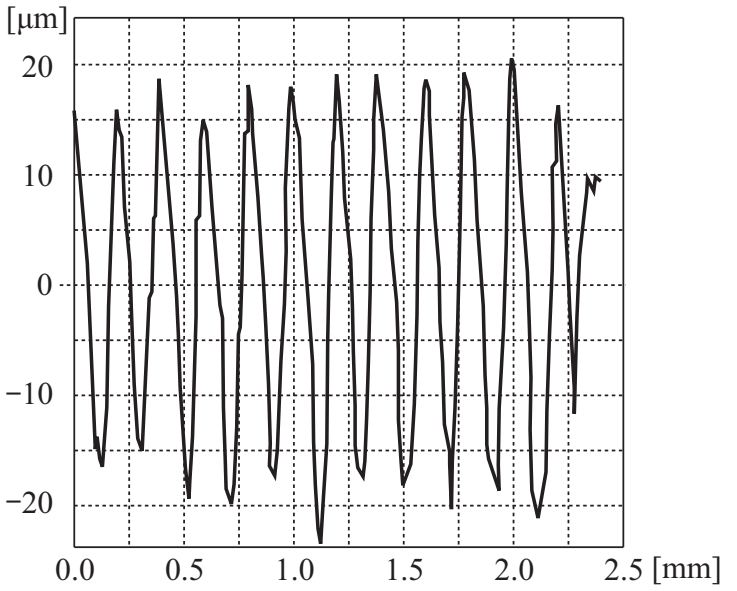

(b) Roughness curve of (a), $10.72 \mu \mathrm{mRa}$

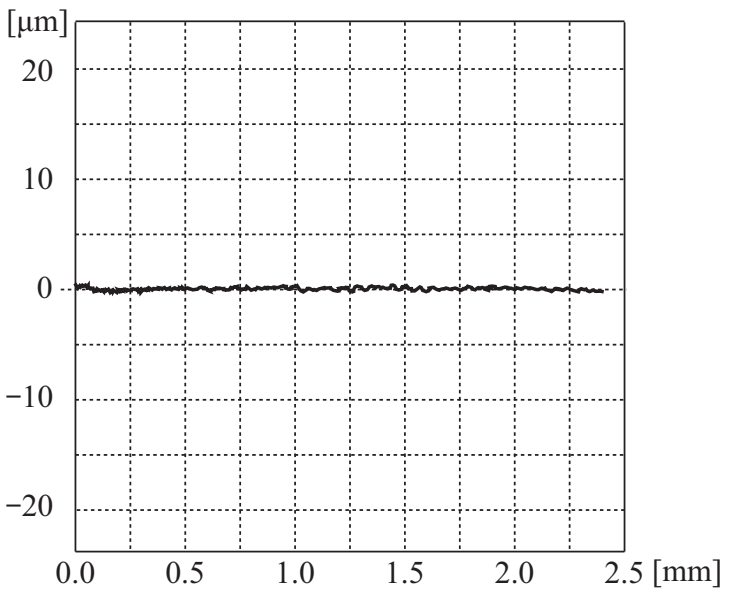

(d) Roughness curve of (c), $0.12 \mu \mathrm{mRa}$

Fig. 20 Comparison of milling and polishing surface

各研磨工程で得られた撮像画像に対して , カッターマークの検出を行った . 図 21 は，6工程目までカッターマー クが目視て確認できた撮像点 No.49 に対する検出結果である .この撮像点のように，研磨前では検出数が 2,000 を 超えた点が確認できた . 各研磨工程で残存していたカッターマークが検出され，研磨工程の進行とともに除去さ れる樣子か確認できる .

光沢面が得られた 7 工程目では, カッターマークは検出されていない. 他の全ての撮像点においても, 7 工程目 の撮像画像からはカッターマークは全く検出されず，良好な研磨面であることが自動的に判定された．

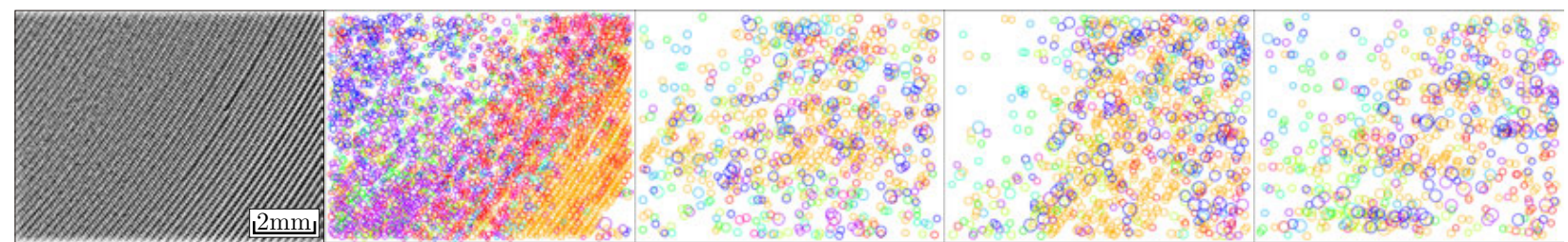
(a) Image of 0th
(b) 0 th $(2,030)$
(c) 1 st (796)
(d) 2nd (931)
(e) $\operatorname{rrd}(669)$

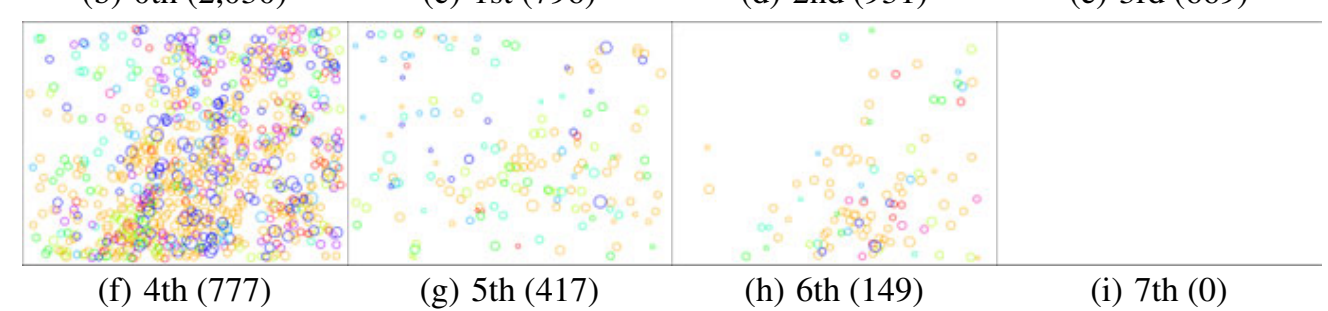

Fig. 21 Results of cutter mark detection (Capturing No.49), polishing process and No. of detected 


\section{8. 結 論}

本研究では，産業用ロボットを用いて切削面のカッターマークをすべて除去する研磨作業を自動化するために， カッターマークパターンを直接検出することができる統計的パターン認識を用いた外観検査について検討した . ま た，統計的パターン認識に不可欠な要素である，大量の学習パターンの収集手段を提案した . 最後に曲面の研磨 実験を行うことにより，以下の結論を得た .

1. 構築した分類器によって，研磨面の撮像画像に残存するカッターマークパターンを判定することができた .

2. 学習画像群を大量に収集する手法を開発して，サンプル収集における膨大な作業量を軽減し，分類器の構築 を平易化した。

3. 研磨実験を行った結果, カッターマークが残存している研磨不良面ではカッターマークが検出され，十分に 研磨された光沢面では検出されないことを確認した . 弚の結果, カッターマーク有無の判定の自動化を実現 した.

$$
\text { 文献 }
$$

(1) Asakawa, N. and Takeuchi, Y., "Dexterous Polishing of Sculptured Surfaces by an Industrial Robot - Automatic Selection of I-Shaped and L-Shaped Rotational Tools -”, In Proceedings of 29th CIRP Int. Seminar on Manufacturing Systems (1997), pp. 370 - 375.

(2) Morishige, K. , Ueki, Y., Ishida, T. and Takeuchi, Y., "Automation of Polishing Process with Industrial Robots - Polishing Path Generation in Consideration of Surface Curvature -", In Proceedings of the International Conference on Leading Edge Manufacturing in 21st Century, Vol. 1 (2005), pp. 109 - 114.

(3) Imadu, D. and Morishige, K. , "Automation of Polishing Process with Industrial Robots - Evaluation of Polished Surface by Using Image Processing -”, In Proceedings of The Japan Society for Precision Engineering, 2006 Spring Semestrial Conference, (2006), pp. 1159 - 1160.

(4) Ito, T. and Morishige, K. , "Polishing Process Automation by Industrial Robots with Polished Surface Quality Judged Based on Image Processing”, International Journal of Automation Technology, Vol.3 (2009), pp. 130 - 135.

（5）木村博志, 松岡博, 森芳弘, 近藤禎樹, 榊原 聡, “多機種の製品に適用可能な高速検査ロボットシステムの開発”, デンソー テクニカルレビューVol.9, No.1 (2004) , pp. 100 - 108

(6) 生田岡一, 松岡博, 森芳弘, 近藤禎樹, 榊原 聡, “外観検査における欠陥特徵の自動学習”, 電子情報通信学会技術研究報 告 Multimedia Virtual Environment マルチメディア・仮想環境基礎 106(157) (2006), pp. 43 - 47.

（7）樋口静一，本橋康之，“テクスチャ解析によるへアライン仕上面の評価方法”, 精密工学会誌 Vol. 70, No. 8 (2004) , pp. 1059 $-1264$.

（8）樋口静一，土屋将，“画像処理を利用する加飾研磨仕上げ面性状の定量化”，精密工学会誌 Vol. 75, No. 10 (2009)，pp. 1233 $-1237$.

(9) Lienhart, R. and Maydt, J. , “An Extended Set of Haar-like Features for Rapid Object Detection”, The Institute of Electrical and Electronics Engineers, The International Conference on Image Processing, Vol.1 (2002), pp. I-900 - I-903.

(10) Viola, P. and Jones, M. , "Rapid Object Detection using a Boosted Cascade of Simple Features", The Institute of Electrical and Electronics Engineers, Computer Vision and Pattern Recognition, Vol.1 (2001), pp. I-511 - I-518.

(11) Freund, Y. and Schapire, R. E. , "Experiments with a new boosting algorithm", In Proceedings of International Conference on Machine Learning (1996), pp. 148 - 156.

(12) Freund, Y. and Schapire, R. E. , "A Decision-Theoretic Generalization of On-Line Learning and an Application to Boosting", Journal of Computer and System Sciences, 55(1) (1997), pp. 119 - 139.

(13) 石田皓之, 高橋友和, 井手一郎, 村瀬洋, 榎本光宏 , “道路標識認識のための学習データ生成手法の検討”, 画像の認識・ 理解シンポジウム $(2005)$

(14) Sharma, B. and Thota, R. , Vydyanathan, N. and Kale, Amit, "Towards a robust, real-time face processing system using CUDAenabled GPUs", High Performance Computing, 2009 International Conference on (2009), pp. 368 - 377 